\title{
Higher Education Loans Board in Kenya from the Islamic Sharia Perspective
}

\author{
MANSWAB MAHSEN ABDULRAHMAN ${ }^{1}$
}

\begin{abstract}
Education loans were introduced in 1952 in Kenya under higher education loan fund board (HELF). The number of applicants increased consequently causing problems in provision of loans by the government; in this regard, the government introduced Students Loans Scheme (USLS), which was governed by the Ministry of Education. USLS noted problems in recovering matured loans from the beneficiary. To deal with this problem, in July 1995 the Government of Kenya through Parliament established the Higher Education Loans Board (HELB) to control the Student Loans Scheme. However, due to financial constraints, education loans do not cater for students studying abroad and those on self-sponsored programs. The scheme contains the element of interest which makes the product non sharia compliant, this is the research problem. Therefore, there is a need to seek an Islamic alternative model based on Islamic sharia. The research methodology to be applied in this study is the inductive and descriptive analysis methods. The Islamic alternative model are expected to help Muslims students to finance their higher education without destroying their faith, likewise HELB will continue funding education loan without hardship thus promoting financial system development and investment in human capital.
\end{abstract}

Keywords: education, higher education loan, Kenya, sharia, student loan

The Higher Education loan board has financed more than 645,000 students since its establishment to pursue further studies in both public and private universities, technical training institutes and polytechnics (HELB Magazine 2018: 06). In 2018 the higher education loan board set a budget of 11.2 billion shillings to support 264,000 students who are pursuing higher studies while the government of Kenya through the national treasury availed 7.7 billion shillings (HELB Magazine 2018: 06) Financing of higher education is helping the government to achieve the big Four Agenda. "The Big Four Agenda of enhancing manufacturing sector, food security and nutrition, affordable universal health care and affordable housing" (Mutuko 2020: 2). This cannot be achieved without investment of human resource. On the other hand, seeking knowledge is obligatory on every Muslim "Are those equal, those who know and those who do not know?" (alQuran 39: 9). Allah said again "Allah grants wisdom to whom He pleases and to whom wisdom is granted indeed he receives an overflowing benefit" (al-Quran 2: 269). The main goal of HELB is to ensure every Kenya gets funding and allowing him to pay back gradually with interest. In such manner, former beneficiaries are on default denying the board a staggering Sh8.5 billion (HELB Magazine 2018: 06). This may occur because of unemployment or if a beneficiary loses his/her job or suffers a big loss in the business thus he may not be capable to repay his/her debt. In this effect, failure to repay the amount fixed by HELB will have a penalty of a minimum of KSh 5,000.00 which is charged every month if one continues to default the payment.

\footnotetext{
1 Manswab Mahsen Abdulrahman, Ph.D, lecturer at School of Sharia and Islamic Studies, Umma University, KAJIADO, Republic of Kenya, email: Manswab83@yahoo.com.
} 
From the above background view, this study aims to analyze the type of loan product provided and other transactions from the Shariah perspective. Specifically, it focuses on seeking an Islamic alternative model based on the concept of waqf which refers to holding a property under the ruling of Allah and giving charity from its income (Al-Mirghany n.d.: 67) The legitimacy of waqf has been implicitly mentioned in the Holy Quran in some verses. Among them: "O you, who have believed, spend from the good things which you have earned and from that which we have produced for you from the earth. And do not aim toward the defective there from; spending [from that] while you would not take it [yourself] except with closed eyes. And know that Allah is Free of need and Praiseworthy" (al-Quran 2: 267). As far as waqf is concerned, there are many hadiths that reinforce its legitimacy. One of them is:

Narrated by Ibn Umar (R.A) said: Omar (R.A) said to the Prophet (SAW): "I have acquired a piece of land. Never have I acquired land more loved by me and more cherished by me than this (land from lands of Khaybar). So what do you command me to do with it? Thereupon he (Allah's Apostle) said: If you like, you may keep the corpus intact and give its produce as sadaqa (charity)" (al-Tirmidhi n.d.: 650).

The model is also based on qard hassan which is giving money for the sake of Allah to the borrower which he has to return at end of agreed time without any interest (Al-Qeraweny. n.d. 455). The evidence from Quran which permissible of qard hassan: "Who is it that would loan Allah a goodly loan so He may multiply it for him many times over? And it is Allah who withholds and grants abundance, and to Him you will be returned" (al-Quran 2: 245). Qard hassan is highly encouraged in Islam; because it assists the needy people in order to establish a better relationship amongst themselves. The borrower is required to repay the amount without any interest since it's not permitted in Islamic law and would be considered as riba-means "the loan given for a specified period on condition that on the expiry of the period, the borrower will repay it with excesses" (al-Jassas 1347: 451-465). This study contributes to the discussion of Islamic student's loan to be introduced in the Higher Education Loan Board from the Islamic Sharia perspective.

\section{A Historical Overview of HELB in Kenya}

Kenyan students started receiving education loans during the colonial period back in 1952, through the board known as HELF (Higher Education Loan Fund). The board offered education loan for those who pursued further studies outside East Africa especially in Great Britain, the USA, India, the USSR, and South Africa (Ng'ang'a 2016: 2). The government requested securities such as land title deeds, insurance policies and written guarantees. Later after independence, in 19731974 , the number of applicants increased consequently thus causing problems in provision of loans by the government (Personal Interview 2020:1). In this period the economy of the country was weakening because of oil shock then the government was required to review the policy related to funding scheme because it was no longer sustainable, this led to the introduction of University Students Loans Scheme (USLS). Under the scheme, Kenyan students who were pursuing further studies at Makerere, Nairobi and Dar es Salaam universities received education loans which covered their tuition fees and personal needs, which they would reimburse on completion of their academic programs (Personal Interview 2020:1).

In addition, it was made easier for students to apply for loans from their home district instead of university or college campuses, and make this was after endorsement from the chiefs, at this moment the government also introduced meal card known as PAYE (Pay as You Eat), this occurred after government revoked pocket money KSh 5000.00 (64 USD) granted per semester (Boy 2018:10] The board was governed by the Ministry of Education and was not administered by an autonomous body (Otieno 2004: 76). 
In the following years, budget allocations to the Ministry of Education comprising the loan scheme increased progressively from $3.1 \%$ in $1974-1975$ to $6.1 \%$ in $1992-1993$. It was the fastest growing component of university education (Mungai 1989: 20). Even though the Ministry of Education had increased the budget, it faced several challenges such as poor administration, high costs of interest and low recovery of funding. In this regard, Otieno says that:

The legal obstacles also stood in the way of recovery, such as the Limitations of Actions Act which renders unrecoverable any debt not claimed within six years from the time it is due (Otieno 2004: 75-99).

In order to tackle this problem, the government establish the new board known as Higher Education Loans Board in 1995 through Act of Parliament through Kenya Gazette Supplement (Cap 213 A) (Republic of Kenya 1988). Another reform was realized in 1995 when the Higher Education Loans Board set its functions as follows:

To facilitate the payment of loans, scholarships and bursaries to poor Kenyan students also to pick up all outstanding loans given to former university students since 1952 through the Higher Education Loans Fund (HELF) another mandatory is to establish a revolving fund from which funds could be drawn and lent to needy Kenyans pursuing higher education. The government anticipated that this revolving fund would ease national education expenditures, which had been close to $40 \%$ of the national budget and addition to that is to invest surplus funds in any investments authorized by law and last is to seek additional funding from other organizations such as private sector, philanthropic organizations (Boy 2018: 10).

One of the functions of the board is to provide financial support to Kenyan students who continued with the undergraduate program or post-graduate both in national or international universities. This included self-sponsored and those who were sponsored by the government through the Kenya Universities and Colleges Central Placement Service (KUCCPS). In this regard, the students were permitted to obtain the education loan for maximum of 6 years in their education life cycle; this is depending on numbers of years and types of loan (Personal Interview 2020:1). In November 2019, higher education loan board published 80,000 students' names and photos of defaulters and gave them 30 days to repay the loan failure to which legal action would be taken against defaulters (Standard 2020: 16). In order to avoid defaults, HELB has introduced an online platform via mobile money transaction (M-pesa).

\section{Qualification for Award of an Education Loan:}

The HELB board made rules and procedures for one who was interested to apply for an academic loan, the conditions and procedures were as follows:

First time applicants to public Universities obtain loan application forms on the HELB website and they should be Kenyan citizens with national identity card. The applicant must be pursuing a degree programme or diploma in a public or private chartered University. Continuing students have to obtain the subsequent forms from the website. They should fill it and take it to the Dean of Students to sign and send the forms to HELB offices (Senior Loans Officer) (Personal Interview 2020:1).

In order to earn an education loan, the applicants are required to get recommendation letter from chief to ascertain that student hails from that geographical area and own Kenya 
citizenship. And are also expected to have the following items: National Identity Card (ID), KRA Pin, Parents Identity Card, Guarantors Identity Card, Parents Pay Slips, affidavit from advocates, death certificate in case of parent's death. In addition to that the applicant must have been enrolled into universities or colleges and must have scored a minimum grade of C+ (plus) in the Kenya Certificate of Secondary Education (KCSE) and be able to prove the KCSE result slip (Boy 2018: 40-41).

The report shows that since HELB was established it has financed over 645,000 students spending q total amount of KSh72 billion. Those who have fully refunded their loans are 113,000 of the total amount of KSh13 billion, while 136,000 students are already refunding KSh 31 billion. Besides, 264,000 students possess Sh29 billion because their loan has not matured while former beneficiaries were denying repaying KSh 8.5 billion this required to collect the balance of KSh 4.5 billion through loan recovery and partnerships. In 2018 the higher education loan board had arranged a budget of KSh11.2 billion to assist 264,000 students while the government through the National Treasury was reward KSh 7.7 billion (Ringera 2018: 6).

\section{Repayment of Higher Education Loan in Kenya}

A graduate from university or college is supposed to refund the loans upon completion of studies. The higher education loan board may propose one financial year moratorium or recollect the loan whichever is earlier. However, it's allowed to pay the balance in advance to reduce his/her balance in good time (HELB Handbook 2018: 4-5). According to the Higher Education Loan Board guideline, those salaried who take loans its obligatory to clear their loans after disbursement. It is also stated in the Higher Education Loan Board Act 213 "The employer shall pay every deduction from the loanee's wages or remuneration in the prescribed manner to the Board within 15 days after the end of each month" (HELB Act 1995: 12). An Employer is required to deduct the loan installments from the salary and not exceed $25 \%$ of a lonees' basic salary after that deposit to the Higher Education Loan Board within 48 month after disbursements (Personal Interview 2020:1). The minimum amount that HELB has set for unemployed is KKh 1500.00 (Personal Interview 2020:1). For undergraduate student's loan repayment begin after completion of the studies within one year or within the period as higher education loan board decide to recall. It's also allowed to clear the balance before or after completion of the studies (Kipkech 2011).

The government of Kenya through HELB set supplementary charges to repay the education loan as follows:

\section{Ledger (Administrative) Fee}

Students who are qualified to apply for an education loan will receive funds after second semester in the first year of the study. In addition to that loan he will be awarded twice in a semester. This makes seven semesters instead of eight, for those who take academic program of four year. The following table shows amount of money and how it's awarded for beneficiaries (Boy 2018: 41).

Table 1: Loan Disbursement to GSSP Students

\begin{tabular}{|c|c|c|c|c|c|c|}
\hline \multirow[t]{2}{*}{$\begin{array}{l}\text { Loan } \\
\text { Awarded } \\
\text { by HELB }\end{array}$} & \multirow[t]{2}{*}{$\begin{array}{l}\text { Administra- } \\
\text { tion Fee } \\
\text { (KSh) }\end{array}$} & \multicolumn{2}{|c|}{$\begin{array}{l}\text { Amount Disbursed to the } \\
\text { University by HELB as } \\
\text { Tuition (KSh) }\end{array}$} & \multicolumn{2}{|c|}{$\begin{array}{l}\text { Amount Disbursed to the } \\
\text { Student's Personal Account } \\
\text { (KSh) }\end{array}$} & \multirow[t]{2}{*}{$\begin{array}{c}\text { Grand } \\
\text { Total (KSh) }\end{array}$} \\
\hline & & 1st Sen & 2nd Sem. & 1st Sem & 2nd Sem. & \\
\hline $35,000.00$ & 500.00 & $4,000.00$ & $4,000.00$ & $13,750.00$ & $12,750.00$ & $34,500.00$ \\
\hline $37,000.00$ & 500.00 & $4,000.00$ & $4,000.00$ & $14,250.00$ & $13,750.00$ & $36,500.00$ \\
\hline $40,000.00$ & 500.00 & $4,000.00$ & $4,000.00$ & $16,250.00$ & $15,750.00$ & $39,500.00$ \\
\hline $45,000.00$ & 500.00 & $4,000.00$ & $4,000.00$ & $18,750.00$ & $17,750.00$ & $44,500.00$ \\
\hline $50,000.00$ & 500.00 & $4,000.00$ & $4,000.00$ & $21,250.00$ & $20,250.00$ & $49,500.00$ \\
\hline
\end{tabular}


The above table indicates the minimum and maximum amount provided by HELB to applicants is between KSh 35,000.00 and KSh 50,000.00 for Government Sponsored Student's Programme (GSSP). The difference in amount depends on the status of the applicants which is determined by a process known as Means-Testing by HELB authorities. After all the process, HELB deducts KSh 500.00 as administration fee remaining with KSh 34,500.00. Out of this amount, KSh. $8,000.00$ is directly granted to the University as tuition fee for the two semesters. Half of the remaining amount is directly deposited to the students account for the upcoming of two semesters.

Table 2: Loans Disbursement to PSSP Students

\begin{tabular}{|c|c|c|}
\hline $\begin{array}{c}\text { Loan Awarded by HELB } \\
\text { (KSh) }\end{array}$ & $\begin{array}{c}\text { HELB Administration Fee } \\
\text { (KSh) }\end{array}$ & $\begin{array}{c}\text { Amount Paid to the University by } \\
\text { HELB (KSh) }\end{array}$ \\
\hline $35,000.00$ & 500.00 & $34,500.00$ \\
\hline $37,000.00$ & 500.00 & $36,500.00$ \\
\hline $40,000.00$ & 500.00 & $39,500.00$ \\
\hline $45,000.00$ & 500.00 & $44,500.00$ \\
\hline $50,000.00$ & 500.00 & $49,500.00$ \\
\hline
\end{tabular}

Majority of Privately Sponsored Students Programme (PSSP) who do not meet the university or college admission requirements had a different plan, KSh 500.00 is deducted from their amount as administration fee and the rest of amount is deposited to the university or college, nothing is deposited to the student for saving or upkeep. Boy explained the status of needy students after he conducted an interview with the senior officer saying "Extremely needy applicants may receive a bursary in addition to loan." In trying to find out how HELB disburses the loans to the students in interview, the Senior Loans Officer said that they disburse the money to personal bank accounts for KUCPS less Kshs 8000.00 tuition or to University account for PSSP students less KSh 500.00 as administration fee (Boy 2018: 42).

According to the previous case, it is mentioned clearly that higher education loan board deducts KSh 500.00 which is equivalent to USD 5 from their amount as administrative fee; this is permissible based from Quranic verse "They said: We are missing the measure of the king. And for he who produces it is [the reward of] a camel's load, and I am responsible for it" (al-Quran 12: 72) other evidence from Sunnah narrated by Abu Sa'id Khudhri reported that:

"Companions of the prophet came across a tribe amongst the tribe of Arabs, and that tribe did not entertain them. While they were in the state, the chief of that tribe was bitten by a snake. They said "have you got any medicine with you or anybody who can treat with ruqya? The prophets companions said, "you refuse to entertain us, so we will not treat unless you pay us for it. "so they agreed to pay them a flock of sheep. One of them started reciting Suratul al-fatiha and gathering his salvia and spitting it (at the snake bite) the patient got cured and his people presented the sheep to them, but they said "we will not take it unless we ask the prophet (whether it is lawful) when they asked him, he smiled and said, How do you know that Surah al-Fatihah is a Ruqya? Take it (flock of sheep) and assign a share for me" (Bukhari 2001: 131).

Furthermore, majority of contemporary Muslim scholars allowed financial institution to charge service fee (ju'ala) provided that it reflects actual incurred cost. This opinion was derived from fiqh council Jeddah released a statement on credit card and taking fees as follows:

(a) It is permissible for the one who issues the card to charge set fees when issuing or renewing a card, because these are fees to cover actual services (b) It is 
permissible for the issuing bank to take commission from the company that accepts this card and sells on that basis, provided that the company sells the product by credit card for the same amount as it sells if for cash. Cash withdrawals by the card carrier are a loan from the issuer, and there is nothing wrong with that from a shar'iah point of view so long as it will not result in interest. Set fees that are not connected to the amount or length of this loan are not regarded as interest. Any charges in addition to the set charges, such as if the charges exceed the amount required to cover the services offered, are haram because that is riba which is forbidden in shariah, as was stated by the council in its report no. 13 (10/2) and 13 (1/3). (Majallah Majma' Al-Fiqh, No 12, Vol 3: 459).

On the other hand, the resolution of Council of Scholarly Research and Ifta, Vol.13 (n.d: $415)$ state on issue relating on charging fee as follows:

If the costs are estimated by those who are experienced and skilled in terms of operations and finances for the benefit of the project, then they have the right to take fees from the project. Nevertheless, it is more preferred if they considered it to be an assistance towards the project owner.

Nevertheless AAOIFI (2010) Shari'ah Standards state that: "It is permitted for the institution which gives out financings to impose fees for the services rendered - a fee reflecting the amount of actual incurred cost, and it is prohibited for those institutions to charge more as every surplus up and above the cost of actual expenses is unlawful".

Therefore, it is permitted for HELB to charge loan with administrative fee on loan financing to repay actual administrative expenses associated with the loan. This differs from interest in that the administrative fee is the actual expense incurred by HELB, while interest is payment for the use of the loan financing.

\section{Interest Loan}

Higher Education Loan Board subsidizes the actual fee of interest rate on loans beneficiary, the interest rate charged with higher education loan board is lower as compared to financial institutions. The following table indicates interest charged per annum (HELB Handbook 2018: 4).

Table 3: Interest Charged Per Annum

\begin{tabular}{|l|l|l|l|l|}
\hline No & \multicolumn{1}{|c|}{ Items } & \multicolumn{1}{|c|}{$\begin{array}{c}\text { Interest rate } \\
\text { per annum }\end{array}$} & \multicolumn{1}{|c|}{ Level of studies } & \multicolumn{1}{c|}{ Target Group } \\
\hline 1 & $\begin{array}{l}\text { Undergraduate Loan- } \\
\text { Direct Entry }\end{array}$ & $4.0 \%$ & Undergraduate & $\begin{array}{l}\text { All Kenyan direct entry } \\
\text { undergraduate students }\end{array}$ \\
\hline 2 & $\begin{array}{l}\text { Continuing Education } \\
\text { Loan } \\
\text { (Salaried Students) }\end{array}$ & $12.0 \%$ & $\begin{array}{l}\text { Undergraduate, } \\
\text { Masters \& } \\
\text { Ph. D. }\end{array}$ & $\begin{array}{l}\text { All Kenyan students } \\
\text { employed in } \\
\text { compliant companies in } \\
\text { Kenya }\end{array}$ \\
\hline 3 & TVET Loan & $4.0 \%$ & Certificate \& Diploma & $\begin{array}{l}\text { All Kenyan Diploma \& } \\
\text { Certificate students } \\
\text { enrolled in TVETA \& } \\
\text { KATTI registered Colleges }\end{array}$ \\
\hline 4 & $\begin{array}{l}\text { KRA Training } \\
\text { Revolving Fund }\end{array}$ & $4.0 \%$ & $\begin{array}{l}\text { Certificate, Diploma, } \\
\text { Employees of KRA } \\
\text { Undergraduate, } \\
\text { Masters \& PhD }\end{array}$ & \begin{tabular}{l} 
Employees of KRA \\
\hline
\end{tabular} \\
\hline
\end{tabular}




\begin{tabular}{|l|l|l|l|l|}
\hline 5 & $\begin{array}{l}\text { Public Service } \\
\text { Training } \\
\text { Revolving fund }\end{array}$ & $4.0 \%$ & $\begin{array}{l}\text { Masters \& } \\
\text { PhD }\end{array}$ & Civil service employees \\
\hline 6 & AfyaElimu Fund & $4.0 \%$ & Certificate \& Diploma & $\begin{array}{l}\text { All Kenyan students } \\
\text { enrolled in Medical } \\
\text { Training Colleges }\end{array}$ \\
\hline 7 & $\begin{array}{l}\text { County \& } \\
\text { Constituency } \\
\text { Education } \\
\text { Funds }\end{array}$ & $4.0 \%$ & TVET \& Undergraduate & $\begin{array}{l}\text { Kenyans from the } \\
\text { sponsoring county } \\
\text { or constituency }\end{array}$ \\
\hline 8 & Partnership Funds & $4.0 \%$ & $\begin{array}{l}\text { Certificate, Diploma \& } \\
\text { Degrees }\end{array}$ & $\begin{array}{l}\text { Dependent on partner } \\
\text { requirements }\end{array}$ \\
\hline
\end{tabular}

According to the table, it is mentioned clearly that the beneficiary must repay the loan with interest of $12.0 \%$ or $4.0 \%$ which is not permitted in Islamic law for the borrower to bring addition return to the lender because that would be considered as riba, in Arabic language refers to increase (Ibn Manzur 1986: 304-307). From shariah point of view riba may be defined as "the loan given for a specified period on condition that on the expiry of the period, the borrower will repay it with excesses" (al-Jassas 1347: 451-465). There are much textual evidence from the Quran and Sunnah which prohibits trading on interest. Allah said: "The usury (interest) that is practiced to increase some people's wealth, does not gain anything from God. But if you give to charity, seeking God's pleasure, these are the ones who receive their reward many fold." (al-Quran 30:39).

From Sunnah, it is narrated by Ibn Mas'ud, (R.A) "The Prophet cursed the receiver and the payer of interest, the one who records it and the two witnesses" (Ahmad bin Hanbal 1995:10). Muhammad Abu Zuhra (1986: 24) contributes that: "Any predetermined payment over the above actual amount of principal sum is prohibited in Islam". Riba is prohibited because its unjust i.e. HELB takes addition amount to the students and it will end after graduation without earning job opportunity. The Quran makes a clear evidence that borrower should be treated with ease and not more difficult. Allah said, "If the debtor is in a difficulty, grant him time till it is easy for him to repay. But if ye remit it by way of charity, that is best for you if ye only knew" (al-Quran 2: 280] This verse provides a great examples in promoting brotherhood and welfare in the society, according to the verse many values are realized and promoted like the values of tolerance, understanding each other and empathy. This verse also instructs us not to be too obsessed with the gathering of wealth. Indeed, it reminds us the life of the Day of Judgment and therefore what should matter most in our life is the accumulation of Allah's pleasure.

\section{Penalties Charged for Non-Repayment of Student Loan}

A default occurs in two ways when the debtor does not make the required payment or does not comply with rules and regulation of a loan (Al-Tamimi \& Al-Mazrooei 2007: 394-396). This happen when the beneficiary does not fulfill some agreements to repay the loan to the lender, default of the loan may cause lack of sufficient fund hence some of applicants will not awarded the loan. Failure to repay the amount fixed by HELB will penalize of minimum of KSh 5,000.00 which is charged every month if one continues to default the payment (Laws of Kenya 1995: 11). In addition to that Higher Education Loan Board cooperates with Credit Reference Bureau (An organization that is accredited by the Central Bank of Kenya to collect and distribute credit information to reduce the loan default risk) therefore the default on loan will be blacklisted by the Bureau (Tuko Best Digital News Platform 2020: 1), from securing personal loan, car as well as credit card facilities. In case a default occurred in payment, it is not permitted any penalty to be charge in Islamic law, only actual loan or debt collection may be imposed. The reason for prohibition of such penalties is that they fall under interest in Islamic jurisprudence. Allah said: 
"If the debtor is in a difficulty, grant him time Till it is easy for him to repay. But if ye remit it by way of charity, that is best for you if ye only knew" (al-Quran 2: 280).

Thereby, it is not allowed to charge anything extra on the capital even after expiry of the period in which payment should commence. The real solution for this problem is to obtain collateral. It is allowed in Islamic law to protect creditor (financial institutions) against default by borrower, this idea is derived from the Quran and Sunnah from the concept of al-rahn (pawning) which mean "possessions offered as security for a debt so that will be taken from it in case the debt failed to pay back the money" (Mohammad 1993:63). Allah said: "And if you are on a journey and cannot find scribe, then a security deposit (should be) taken" (al-Quran 2: 283). Also narrated by 'Aisha (R,A): "Allah's Messenger (PBUH) bought food grains from a Jew on credit and mortgaged his armor to him". (al-Bukhari 1987:80). If the borrower not able to bring collateral, he is required to present a guarantor, who may become liable in case of any default based on the hadith: "The guarantor is responsible, and the debt must be repaid" (Abdallah 2009: 3). In the event of default or a deceased person the collateral item (rahn) will be auctioned off and any surplus would be returned to the borrower.

Based on the previous discussion, it is clear that, loan which is offered by higher education loan board is inconsistent with Islamic law because it is contains the element of interest (riba) which is forbidden under sharia law. Furthermore, type of riba is categorized as riba al-nasi'ah which refers to a certain duration given to lender for repayment of loan in return for extra payment. Any predetermined payment over the above actual amount of principal sum is prohibited in Islam (Muhammad Abu Zuhra 1986:24). Therefore, it is not allowed for Muslim students to apply for higher education loan; because the messenger of Allah cursed the one who accepts the riba and the one who pays it.

\section{The Proposed Islamic Student Loan in Kenya}

The Islamic model contemplates the participation of three key agents throughout the process: Students, Higher Education Loan Board and Waqf Institution which relies on immovable property such as agricultural land, commercial building etc., the income from these projects will be used to fund free interest loan (Qard Hassan), to the students who pursue higher education. It requires a Muslim student to apply for the loan from a waqf institution; once he/she obtains approval he/she must go to the HELB office to sign legal documents, the student who receives the loan must also sign legal documents in waqf institution. Repayment will be done after graduation and once he/she has secured a job. Repayment can be organized equally to the average inflation rate and lower than interest rates. Instead of paying interest he/she will refund soft loan to the waqf institution without any interest. In case a beneficiary fails to repay the benevolent loan the waqf institution (lender) must accept it as charity. This circulation of money will benefit needy students to complete their studies. Therefore, members assist each other to obtain higher education. In this regard Allah said: "And cooperate in righteousness and piety, but do not cooperate in sin and aggression" (al-Quran 5: 2). Nevertheless, incomes from waqf institution can be invested in the low-risk project and the profit will go back to operating expenses to finance Muslim students. This Islamic model will be self-financing, implying that it has excess fund to disburse for educational loans. As such, the profits obtained from the low-risk investment will be utilized to support students who pursue further studies in universities and colleges.

The study concluded that, the establishment of Islamic Waqf Student Loan will help Muslims finance their higher education without sacrificing their faith. They will no longer have to worry about paying back the loan because the waqf organization shall stand as guarantor. The process of establishing an Islamic Waqf Student's Loan body will become a relief for the Muslim students in the Republic of Kenya. 


\section{References}

Accounting and Auditing for Organization of Islamic Financial Institutions (AAOIFI). 2010. Shari'ah Standards for Islamic Financial Institutions. Bahrain: AAOIFI.

Abdallah bin Yazid al-Qazwein. 2009. Sunan bin Majah. Vol. 5. n.l.: n.p.

Ahmad bin Hanbal. 1995. Musnad Imam Ahmad bin Hanbal. Egypt: Darul-Hadith.

Ali Abubakar al-Mirghany. Al-Hidayah fi Sharh Bidayat Al-Mubtadi. Beirut: Dar al-Fikr.

Boy, Josephine Sakwa. 2018. An assessment of higher eduction loans board in financing university education in Kenya: A case of Moi University. Thesis Master of Art. Moi University, Kenya.

Al-Bukhari, Muhammad bin Ismail. 2001. Sahih Al-Bukhari. Vol. 7. n.l.: Dar Touq Al-Najat.

Al-Bukhari, Mohammad Ismael bin Mughira. 1987. Al-Jami`Sahih. Vol. 1. Cairo: Dar al-Sya`b.

HELB Officers. 2020. Anniversary Towers, Nairobi-Kenya. Personal Interview, 13 January.

Higher Education Loan Board. 2018. HELB Handbook. Nairobi: HELB.

Ibn Manzur. 1968. Lisan al-Arab. Vol. 14. Beirut: Dar Sadir li Taba'ah wa al-Nashr.

Al-Jassas, Abubakr. 1347. Ahkam al-Qur'an (The Quranic Judgements). Cairo: Al-Matba'ah alBahiyyah.

Kipkech, J. R. n.d. Determinants of Students Loan Default; A Case of the Higher Education Loans Board. Unpublished MBA Research Paper. University of Nairobi.

Laws of Kenya. 1995. Higher Education Loan Board Act Chapter 213A. National Council for Law Reporting with the Authority of the Attorney-General.

Majallah Majma` Fiqh Islami. 1986. Majallah Majma`Fiqh Islami 1(3): pp. 459.

Mohammad bin Ahmad Sarakhsi. 1993. Al-Mabsut. Beirut: Darul al-Ma`rifah.

Muhammad Abu Zuhrah. 1986. Bukhut fi Riba. Cairo: Dar al-Fikr.

Mungai, M. 1989. University Education in Kenya: Trends and Implications for Cost, Finance and Occupations. Nairobi: Ministry of Education/World Bank.

Mutuko, Ryan. 2020. The big four agenda of the government explained. https://www.tuko. co.ke/ 313484-big-four-agenda-government-explained.html. Retrieved: 1 Feb. 2020.

Ng'ang'a, Monica N. 2016. Factors Affecting Repayment of Education Loan among University Students Kenya. A Research Dissertation Submitted in Partial Fulfillment of the Requirements for the Award of Master of Science in Commerce Degree in the School of Business and Public Management at KCA University.

Otieno, W. 2004. Student loans in Kenya: past experiences, current hurdles and opportunities for the future. Boston College \& Council for the Development of Social Science Research in Africa. Journal of Higher Education in Africa 2(2): 75-99.

Otieno, Wycliffe. 2004. Student Loans in Kenya: Past Experiences, Current Hurdles, and Opportunities for the Future. Boston College \& Council for the Development of Social Science Research in Africa.

Republic of Kenya. 1988. Report of the Presidential Working Party on Education and Manpower Training for the Next Decade and Beyond. Nairobi: Government Printer.

Ringera, Charles M. 2018. Employers at the centre of loan recovery. The Compass Magazine Higher Education Loan Board. 26th edition, pp. 6.

Standard. 2020. Helb vows to name and shame loan defaulters in 50 billion debt, https://www.standardmedia.co.ke/article/2001349835/helb-to-publish-defaulterslist-of-shame. Retrieved: 16 Feb. 2020.

Al-Tamimi, H.H \& Al-Mazrooei. 2007. Banks risk management: a comparison study of UAE national and foreign banks. Journal of Risk Finance. 8(4): 394-396.

The Islamic Fiqh Council. n. d. Statement of the Fiqh Council on credit cards and taking fees for them 23-28/sep/2000 http://www.iifa-aifi.org/2055.html. Retrieved: 2 Dec. 2019.

Tirmidhi. n.d. Sunan al-Tirmidhi. Vol. 3. Cairo: Dar al-Hadith.

Tuko best digital news platform. Minimum HELB repayment amount. https://www. tuko.co.ke/ 280098-minimum-helb-repayment-amount.html. Retrieved: 8 Jan. 2020. 